\title{
Acquired Immune Deficiency Syndrome Status in Islamic Countries
}

\author{
Roya Alavi-Naini ${ }^{1^{*}}$ \\ ${ }^{1}$ Infectious Disease and Tropical Medicine Research Center, Zahedan University of Medical Sciences, Zahedan, IR Iran
}

A R T I C L E I N F O

Article type:

Editorial

Article history:

Received: 20 May 2012

Revised: 25 May 2012

Accepted:31 May 2012

Keywords:

Acquired Immune Deficiency Syn-

drome

Islam

Human Immunodeficiency Virus

Acquired Immune Deficiency Syndrome (AIDS) is a social-health problem. Injection drug use, sharing needles and sexual contacts are considered as the main ways of Human Immunodeficiency Virus (HIV) transmission from person to person in Central Asian countries as well as Iran (1). In recent years, the number of people who have died from AIDS is declining while; the number of HIV carriers is also rising. Therefore, the risk of the disease transmission by apparently healthy individuals is alarming. Reduction of risky sexual behaviors has been urged in Islamic canonical principles (Shariat) which has led to a decrease in the incidence of HIV infections in Muslims. On the other hands, prohibition of alcohol use in Islamic codes has resulted in reduction of abnormal behaviors and ultimately decreases the rate of sexually transmitted diseases such as AIDS. Besides, circumcision of Muslim boys as well as cleaning and washing of body after intercourse (ablution) can be enumerated as one of the influential factors in reduction of this disease which in turn can dramatically reduce the other infections incidence. However, some beliefs such as failing to encour-

\begin{abstract}
-Implication for health policy/practice/research/medical education:

Acquired Immune Deficiency Syndrome is a social-health problem all over the world, which has a soaring rate of prevalence. This article emphasize on the low rate of AIDS among Muslims population. This study has implication for researchers and psychological educators as well.
\end{abstract}

- Please cite this paper as:

Alavi-Naini R. Acquired Immune Deficiency Syndrome Status in Islamic Countries. Int J High Risk Behav Addict. 2012; 1(3): 90-1.

Published by NewPub. 2012. cc 3.0.

age condom use and polygamy could lead to increase the risk of some sexually transmitted infections. In general, since the detection of HIV, African countries have been reported as the major zone infected with the HIV. Based on the surveys of the World Health Organization, SubSaharan Africa experienced noticeable decrease in AIDS infection incidence (2). In conducted surveys, six out of seven published articles with the subject of the relationship between religious beliefs and AIDS indicate that AIDS epidemic among the Muslims of Sub-Saharan Africa is less than non-Muslims citizens (3). with reference to World Health Organization reports, Central Asia and Eastern Europe are facing with the alarming increase of known cases of HIV, in such a way that the spread of HIV in some countries in the Middle East and North Africa, including Egypt, Sudan and Tunisia, has been growing and warns among some Islamic countries like an epidemic. It should be noted that the registered cases of HIV infection in many of these countries are much lower than the estimated cases declared by the World Health Organization (4). Obviously, Iran is not an exception. Despite low preva-

\footnotetext{
${ }^{*}$ Corresponding author: Roya Alavi-Naini. Infectious Diseases and Tropical Medicine Research Center, Zahedan University of Medical Sciences, Zahedan, IR Iran. Tel:+98-5413218016, Fax:+98-5413213885, E-mail: ranaini@gmail.com (c) 2012 Zahedan University of Medical Sciences; Published by NewPub. DOI:10.5812/ijhrba.6578 This is an Open Access article distributed under the terms of the Creative Commons Attribution License (http://creativecommons.org/licenses/by/3.0), which permits unrestricted use, distribution, and reproduction in any medium, provided the original work is properly cited.
} 
lence of AIDS in different regions of Iran, it is expected that, in case of improper control and lack of adequate training and education, we will confront an increase in its prevalence around the country. Fortunately, continuous efforts in recent years on this basis have been very valuable in Iran, which is known as the best country in the field of AIDS control in the Middle East, but still there is a long way to achieve the desired result.

\section{Authors' Contribution}

R. Alavi-Naini has written whole of the manuscript.

\section{Financial Disclosure}

None declared.

\section{References}

1. CDC. Human Immune Deficiency Virus Infection in Sistan and Baluchestan. Zahedan: Regional Health Center,Zahedan University of Medical Sciences; 2011.

2. WHO. HIV/AIDS prevalence in Sub-Saharan Africa. 2012; Available from: http://www.who.int/gho/urban_health/ outcomes/hiv_ prevalence/en/index.html.

3. Gray PB. HIV and Islam: is HIV prevalence lower among Muslims? Soc Sci Med. 2004;58(9):1751-6.

4. Hasnain M. Cultural approach to HIV/AIDS harm reduction in Muslim countries. Harm Reduct J. 2005;2:23. 